\title{
Development Mathematics Teaching-Instrument Learning Using Open-Ended Approach To Improve Mathematics Communication Ability And Independent Learning Student
}

\author{
$1^{\text {st }}$ Metha Husya Notika \\ mathematics department \\ State University of Padang \\ Padang, Indonesia \\ methahusyanotika@yahoo.com
}

\begin{abstract}
This study aims to disclose the development process and describe the characteristics of mathematics learning tools using an open-ended approach in improving mathematical communication skills and learning independence of learners in seventh grade that meet valid, practical, and effective criteria. This study is a research and development. The product that will be produced in this research is learning tools in the form of Lesson Plan and Student Worksheet using open-ended approach. The development model used in this research will be the development model adapted from the Plomp model. The ability of communication is an important competency that must be have by students, because besides being able to reason and solve problems, students must be able to communicate their abilities both in oral and written form. Mathematical communication skills as an important part of mathematics have not been achieved optimally in reality. This can be seen from the results of the initial test of mathematical communication skills in the three schools that were observed with an overall average score of $\mathbf{4 7}$ from the maximum value of 100. In addition, independence in learning can be carried out with full responsibility and it's also important. Independent learning can increase self-confidence students, so they can reach their success in the future. Based on various surveys, it's able to show that students in Indonesia have low competence in mathematics and mathematics is still less interested for students. Besides being complicated, mathematical learning is gained by students from limited sources. This happened one of them because of low independence in learning. One solution to overcome problem in communication ability and independence in learning is to provide learning tools. The learning tools to be developed is based open-ended approach, because open-ended approach have openness criteria that can develop their communication activities and also increase independence to find other creative ways.
\end{abstract}

Keywords-Communication Ability, Independent Learning, open-Ended Approach, Learning Tools/Instrument

\section{INTRODUCTION}

In fact the quality of education output of Indonesia is still low when compared with the quality of educational output in other countries, it's causing big disappointment. Especially in today's global era, intense competition can't leave little room for us to improve the quality of our education. Therefore, progress for progress will inevitably have to be done. Mathematical education took one role in this progress. The purpose of learning mathematics one of them is to master the ability of mathematical communication.

Mathematical communication is defined as an event or interrelationships that occur in the classroom environment, where there is a transfer of messages in the form of mathematical materials such as concepts, formulas, or strategies to solve a problem [11]. The ability of mathematical communication according to National Council of Teachers of Mathematics (NCTM) are: (a) Communication is an important part of mathematics and mathematics education; (b) Communication can support students learning new mathematical concepts when they encounter a situation, drawing, using objects, giving verbal statements and explaining, using diagrams, writing, and using mathematical symbols; (c) Students should be given guidance in written communication, ranging from the ability to write, draw, write words and sentences [9]. This study involves three very important intellectual skills and each one related to each other, namely: (1) Ability to express real objects, images, and diagrams in mathematical ideas or mathematical symbols; (2) Ability to explain ideas, situations and mathematical relationships in writing; (3) The ability to express everyday events in language or mathematical symbols.

Mathematical communication skills as an important part of mathematics have not been achieved optimally in reality. This can be seen from the results of the initial tests of mathematical communication skills tested on February 19 to March 1, 2018 in three schools in Padang, this test refers to all three indicators with an overall average score of 47 from the maximum value of 100 . Among the three indicators, students experience problems in each indicator tested.

Revision for the sake of government revision so that the developed curriculum can support more optimal learning. This turned out to cause some negative impacts in the field. Teachers cannot begin to take turns for a change in the short term, so student reference books are limited. Students with low learning independence instead rely solely on the help of their teachers without seeking other references for learning. A complicated textbook with a high level of understanding 
becomes a minus value for students interested in learning. So an interesting and easy device is highly expected for meaningful learning process. In this case, researchers do the development of the device to be a solution to the above problems.

Referring to the above, learning tools are things that educators must prepare before implementing the lesson. Learning tool is a tool or equipment to implement a process that allows educators and learners to do learning activities [12]. Learning devices become guidance for educators in implementing learning either class, laboratory or outside the classroom. Learning tool is a prerequisite for the interaction of optimal learning and teaching. Learning tools also become one of the benchmarks of the success of an educator. Learning tool that will be developed in this research is Lesson Plan and Student Worksheet.

In this study, the device will be developed based on an open-ended approach. Open-ended approach is an approach with the nature of openness, so it can more freely develop student communication skills. One of the ever evolving models to evaluate the mathematical communication skills of learners is the Open-Ended Tasks model [3]. In the model there is an open-ended question that gives students the flexibility to answer correctly with possible reasons or different ways of answering. During 1970s and 1980s, openended approach had emerged as a method to reform mathematics teaching of Japanese classrooms and has been spreading around the world. In the 1990s lesson study, a Japanese style of professional development, become known to other countries [5].

The type of problem used in learning using the openended approach is not routine and open issues. Open issues are grouped into three types: (a) Open processes, meaning problems have many paths to completion; (b) An open answer, meaning that the problem has many correct answers; (c) The way to develop open solved problems means that when learners solve their problems they can develop problems into new problems and can change the conditions of open issues [2]. There are three criteria of open-ended questions that must be considered is the need to be rich with valuable mathematical concepts, the level of questions or levels of mathematics of the problem should be suitable for learners, the question should invite the development of more mathematical concepts continue[6]. The context of learning mathematics using an open-ended approach is (a) Orientation, in the form of motivation; (b) Presenting open issues; (c) Resolving open issues individually; (d) discussion groups for open issues; (e) Presentation of results of group discussions; (f) Concluding remarks, in the form of drawing conclusions or summaries for varied concepts or ideas [8].

One of the important capabilities to develop high-level education is to learn independently. As mentioned above, one of the barriers to the lack of student reference in learning is the student's interest in learning is low, this is due to independence in learning is low too. Garrison [7] says learning independence is an approach whereby learners are motivated to take responsibility and collaborate on selfcontrol and self-management, which is a process of building and confirming the results meaningful and useful learning. Hockings, et al [4]. Describes the independence of learning as: (1) Taking responsibility for self-study; (2) Selecting and setting your own goals; (3) Deciding what, and when and how to learn; (4) Monitor its own progress; (5) Developing the ability to find and evaluate critically; (6) Evaluate and reflect on what has been learned.

The purpose of this study was to describe the development process and describe the characteristics of mathematics learning devices using an open-ended approach in improving the mathematical communication skills and learning independence of students in seventh grade that meet the criteria of valid, practical, and effective. While the difference between this research and previous research is the research on developing a device that uses the latest curriculum, namely the revised 2017 curriculum 2013. The developed Student Worksheet also contains open-ended questions based on daily life, as well as a combination of colors and images that are tailored to the tendency of student seventh grade. Student Worksheet is also equipped with motivations and self-reflection sheets for habituation of student learning independence activities.

\section{METHODS}

The type of research conducted is research development (research and development). Educational and development research is a process used to develop and validate educational products [1]. The product that will be produced in this research is learning tools in the form of Lesson Plan and Student Worksheet using open-ended approach.

Subject in this research is student seven grade in the City of Padang. The type of data in this study consists of two, primary data obtained from observations, interviews, initial tests, and questionnaires. Second, secondary data obtained from reference books and journals.

The development model used in this research will be a development model adapted from the Plomp model. This model consists of three phases: preliminary research, development or prototyping phase, and assessment phase. Formative evaluation carried out using the steps

formative evaluation put forward by Tessmer. The formative evaluation steps are illustrated as in Figure 1 [10].

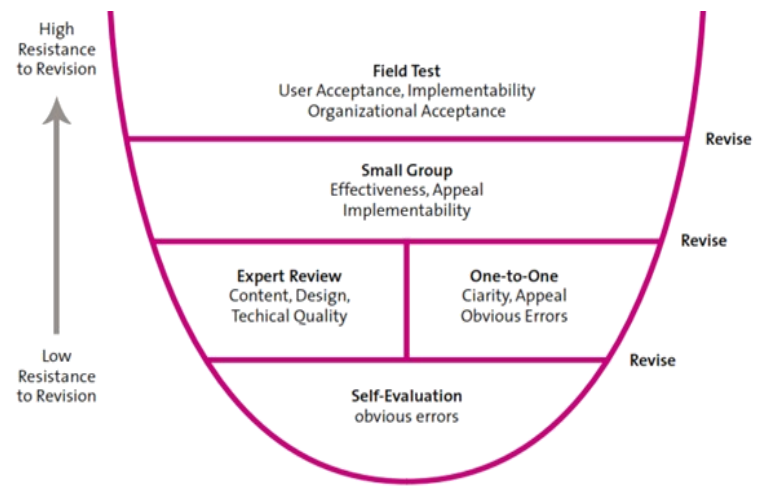

Fig. 1 Formative evaluation steps 


\section{CONCLUSION}

Tools or Instrument for teaching using Open-Ended approach will be developed in this research met the criteria of validity, practicality, and effective.

\section{REFERENCES}

[1] Borg and Gall, Educational Research, An Introduction. New York and London. Longman Inc, 1983.

[2] Fatah. Abdul, et al, "Open-ended approach: an effort in cultivating Students' mathematical creative thinking ability and Self-esteem in mathematics", Journal on Mathematics Education, vol 7, pp. 9-18, 2016.

[3] Fauzan. A, Modul 2 Kemampuan Penalaran dan Komunikasi, Padang: Universitas Negeri Paang, 2012.

[4] Hockings, Christine, et al, "Independent learning - what we do when you're not there", Teaching in higher education, vol. 23, pp. 145-161, 2017.

[5] Inprasitha. M, "Open-Ended Approach and Teacher Education", Tsukuba Journal of Educational Study in Mathematics, 25, 2006.

[6] Mardayanti, Elva, et al, "Pengembangan Soal Open-Ended Menggunakan Konteks Sumatera Selatan Materi Sistem Persamaan Linear Dua Variabel Kelas X SMA”, FKIP Universitas Sriwijaya, vol. 10, 2016.

[7] Mckendry, Stephanie and Vic, Boyd, "Defining the "Independent Learner" in UK Higher Education: Staff and Students, Understanding of the Concept", International Journal of Teaching and Learning in Higher Education, vol. 24, pp. 209-220, 2016.

[8] Murni, "Open-Ended Approach in Learning to Improve Students Thinking Skills in Banda Aceh", International Journal of Independent Research and Studies (IJIRS), vol. 2, pp. 95-101, 2013.

[9] National Council of Teachers of Mathematics (NCTM), Principles and Standards for School Mathematics, America: Key Curriculum Press, 2000.

[10] Plomp, Tjeerd and Nienke, Nieveen, An Introduction to Educational Design Research, Netherlands: Enschede, 2010.

[11] Susanto. A, Teori Belajar dan Pembelajaran di Sekolah Dasar, Jakarta: Kencana Prenada Media Group, 2013.

[12] Zuhdan, et al, Pengembangan Perangkat Pembelajaran Sains Terpadu untuk Meningkatkan Kognitif, Keterampilan Proses, Kreativitas serta Menerapkan Konsep Ilmiah Peserta Didik SMP, Program Pascasarjana UNY, 2011. 